\title{
Intercultural Communication in Indonesia Language Education (Reflection of Attitude Language on Indonesian Language in the Trade Context by Indonesia-Malaysia Border Communities in West Kalimantan)
}

\author{
${ }^{1}$ Netti Yuniarti, ${ }^{2}$ Andoyo sastromiharjo, ${ }^{3}$ Dadang Sunendar, ${ }^{4}$ Yeti Mulyati \\ yuniarty.netty@gmail.com \\ Indonesia University of Education
}

\begin{abstract}
This study aims to describe the attitude language on Indonesia language by the community border in West Kalimantan traced from the experience of learning the language and practice of speaking in the context of international trade. This research is qualitative research with an in-depth interview methods and observations by the Community border in Entikong (West Kalimantan - Indonesia) and in Serikin (Sarawak - Malaysia). The results of this study indicate that the society of merchants and consumers who transact in Entikong (from among adults and students) who trades in the territory of Indonesia tend to use Indonesia language if different tribes or ethnic. In addition, the community of merchants and consumers who transact in Serikin Malaysia region will tend to use Malaysia language who mixed with the local languages. This suggests that the language is determined by the attitude of the situation and the context of the speech is going on. In addition, the context of the second relationship is affected also by intercultural communication skills acquired at school and multilingual language proficiency so that communication in the context of trade.
\end{abstract}

Keywords: Intercultural Communication, Indonesia Language Education, Language Attitude, Trade

\section{INTRODUCTION}

Indonesia is a country with many ethnic groups which automatically has a wide variety of languages. It is reinforced by data development agency and the construction of language[1] that the number of local languages already inventoried and described as much as 652. That number does not include dialects and subdialek for each language. If seen from the accumulation distribution per province, local languages languages in Indonesia totaled 733.

With a number of local languages and cultures that are diverse, patutlah a nation has an official language to unite the various ethnic or tribal. The official languages are important existence to become a unifying standars in terms of intercultural communication. Unifying language in Indonesia is bahasa Indonesia.

In addition to the date of his reign is historically and politically, bahasa Indonesia also increasingly rapid development associated with its function as a media and communications tools. In today's modern era, Bahasa Indonesia increasingly strengthens its existence as a language variety of science. Many books and resources relating to technology-based information were submitted with the language of Indonesia. Its development is getting the message supported by economic development of Indonesia that continues to improve so that the learning interest of foreigners against increasing Indonesia language. This gives you an idea of how the language of Indonesia is ready to menginternasionalisasikan himself as the strong language in Southeast Asia. 
If grounded by data and facts about how powerful the Bahasa Indonesia, then it appears the fundamental question regarding the position and functions of local languages as mother tongues. Regional language serves as the language of instruction in the ethnic community and a very important role as a tribal identity in Indonesia. Thankful things by Indonesia were with wealth and differences in local languages and culture that many of these turned out to be merged with the Indonesia language as an official language. With such complex linguistic symptoms, it can be concluded that Indonesia is a multilingual speakers due at the very least will master the native language (regional language) and Indonesia (official language). It is also in line with the opinion[2] that the people of Indonesia including the multilingual community. The diversity of languages belonging to Indonesia is a multilingual reality which deserves to be examined.

Multilingual symptoms grouped on two terms on the basis of speaker's bilingual (two languages) and multilingal (master more than two languages). In General, Indonesia at least master two languages, namely local languages as first languages and language as a national language of Indonesia. Unlike the language of Indonesia which is the national language and symbol of national identity, if seen from socio-psychological aspects then the regional language was a social identity associated with the ethnic background and identity of a speaker[2]. Regional language for the people of Indonesia on the generally is the first language learned in the process of socialization, although not a possibility that in language acquisition a speakers learn more than one language at a time at one time. The result of that being bilingual came the confusion in determining where the most important language for use in communicating.

In the realm of economic, strengthened the position of the Indonesia language with the use of the language of Indonesia rule in the products marketed in Indonesia. But a little bit different with usha promotions certainly involve lying speak. The society has the freedom to give Indonesia language usage because they wear a medium to showcase, promote the goods/services by making use of the language. Media outside spaces that are clearly plastered with the hope people get to know and are interested in purchasing goods/services that. However, the language used in the naming of or in promotion is often tercampuri by language beyond language Indonesia though there is already legislation linguistic usage. The blended Indonesia language usage by languages beyond language Indonesia, especially in a foreign language.

Entikong border area is very strategic for the development of economic inernasional between Indonesia and Malaysia. The community at the border surely will often interact among Nations if confronted in the context of trade. So is also the case with the communication needs of course complex called intercultural communications.

Early assumptions about intercultural communication are the communication that occurs between people from different countries. In fact it is true, do the communication with people who come from the same country more easily than do the communication with people from different countries. However, when observed, various events in our fatherland, clashes between ethnic strife between the wards, it reflects the existence of a difference in mindset, a way of looking towards life phenomena among the public. In fact, such events occur among people who originate and reside in the same country. Therefore, the basic communications intercultural actually begins from the confluence of antarpersonal (one person opposed to one person).

Can be imagined when communicating with people from other Nations, cultures, and language patterns of his thinking is different. Of course, more complicated compared to the same nation, because it would be prosecuted was able to understand the mindset, culture, even their communications systems. Therefore, understanding the linguistic codes, either verbal or non verbal is absolutely essential to the success of the process of communicating the good, 
true, and correct. This is the importance of the concept of communication intercultural that must be applied in the effort of world countries through dissemination of language education. The concept of multicultural communication education course will also support the efforts of pemertahanan relic in the State language border. Indonesia language education based on the intercultural communication strategy is certainly related to the communications community Entikong in the context of international trade in the region.

The fundamental reason for this research was conducted due to concerns the pemertahanan language of Indonesia is a manifestation of the efforts to maintain and preserve national language. In addition, by knowing the existence among the Indonesian language can give you an idea of what efforts need to be done by Governments, researchers, the community, as well as language pop speakers in areas of West Kalimantan border. Things that can be done by observers and language activists are seeking things related to the world of education in schools in the form of conditioning the use of language of Indonesia and the local language curriculum development. In addition, regarding the linguistic socialization also needs to be done by the related agencies to give to the community in order to be wise in khsusnyaspeaking border region Indonesia with all its complexity. An effort like that in the end not only strengthen the resilience of the tribe through the use of the language in question, but also strengthen the nation's resilience can be simultaneously through the use of the national language.

\section{LITELATURE REVIEW \\ A. Intercultural Communication in Language Learning}

According to Samover[3], intercultural communication occurs when the message sender and recipients of a message based on different cultures. Tokui (in Soepardjo[4]) intercultural communication is the process of defining abstract and integrated activity and definition in the communication between people who have different backgrounds. As for Yasshiro (in Soepardjo[4]) make it clear that communication intercultural the ideal described when people involved in the communication do interpretations of the meaning of the message, collect information, and such information exchange for mutual respect, and cooperation for mutual benefit.

Intercultural communication is generally used in situations of communication directly between people who have different cultures. While the cross cultural communication is used for specific communications and situation compared with some culture. (Tokui in Soepardjo, [4]). Communication intercultural not translated because the conversations between "people of Indonesia with foreigners" or "between men with women", but can occur in conditions of conversation itself. Of course there's communication that does not contain interculturalisme despite good conversation using a foreign language or the language of Indonesia. Hence, language education in Indonesia need to observe any activity once the conversation because there are many things that appear interesting mainly related to communication intercultural.

In communication intercultural often appears "concerns" so-called Communication apprehension [5]. According to Suitable and Cambra[6] in case studies of foreign language learning in students of East Asian countries, concern people When did Japan occupy quite a percentage of a total communication compared to Korea and the Chinese people. Now about the "communication ability yourself", proving the statement. The people of Japan, communication ability based on results of a positive answer, now only $39 \%$ of the rest of the answer is negative. Whereas the communication of foreign students who answer positf is $66 \%$. So, communication apprehension people Japan higher than foreign students who communicate using the foreign language. 
Conditions like this need to get noticed, because its influence is huge against the election strategy of communication with native speakers intercultural languages of Japan. In the end we can avoid the numerous misunderstandings caused by cultural differences in communication between participants. There is again a training intercultural for analyzing the misunderstanding must be through the culture assimilator. This is a way of Attribution training by studying mengintrerprestasikan the occurrence of events that lead to an incident, as seen from the opponent's communication eyewear have a different cultural background.

Realization of training this is a question about the reasons for the occurrence of misunderstanding in communication intercultural. Then against that question provided a choice answers and explanation.. For example, described "incident between Indonesian students who eat together Japan student. He was shocked at the time finished eating each must pay. Then, provided several options of response to the question, why do students feel uneasy seeing Indonesia's stance that Japan people?. For example, the choice of the answer is "because he regarded himself as a foreign student, probably paid for by", "for he thinks will pay first, then he pays his share to the people who pay.", "Because that invites is the supervisor, he thought that the more the seniorlah lecturers pay it ". From the answer choices, to choose the most appropriate answer, but not the way to resolve misunderstandings. Noteworthy is the process of interpretation of events. The choice of the right answer isn't always absolutely correct, because in fact many different things with the statement.

The current language learning activities, in addition to focussing on the 4 skillsspeaking, it should be also emphasized on the ability of cultural understanding speakers of the original, including its communication system. So in speaking, truly implement the fundamental principles of the criminal said proper language. This will occur in the context of international perdaganagn at Entikong in communications which will coincide the individual to choose what language and Chief intercultural accordingly.

A good speaker is a speaker who is able to understand the principles of proper communication. Intercultural communications is one of the models of communication that is important to understand, because communication intercultural not only associated with people from different countries but it is related to how one arranges the information or the message will be accepted and which will be delivered. The differences contained in the communication system of the language will cause much misunderstanding between Its vocabulary or foreign language (Malaysian). This is important existence to instill a positive attitude in Indonesiaspeaking and understanding a foreign language school (Malaysia) dimasyarakat border so that communication works fine. It will help the economy (merchants and consumers) in the border region of transaction.

\section{B. The Border Region Of West Kalimantan}

Description of West Kalimantan border areas referred to in this study refers to the range of research data retrieval area. The researchers chose the location of the research in the Sanggau is one of five counties that are on the leading edge area (border) of Indonesia and Malaysia[7]. It is not necessarily because it has a solid foundation of Dayak Bidayuh community because the majority are in the district and parts of the relic in Sarawak Malaysia. The most appropriate sub to be the location of the research was in district Entikong because right is leading Indonesia and come within an area with a growing border economy. So, Entikong chosen as location research and data retrieval.

Entikong sub district which is in the border between countries is a very strategic area concerns many aspects include:

1. Geographically it is located on the border with the lowliest Serawak (East Malaysia).

2. It is located on the Trans Borneo highway which connects Serawak, Sabah, and Brunei Darusalam. 
3. Have the Entikong border is the official doors in Indonesia as the gate of entry to or exit from Serawak, Sabah, and Brunei Darusalam.

In addition, note that there are still traditional way of linking some of the village in Kecamatan Entikong towards settlements in the region of East Malaysia Serawak. It is closely related to the existence of Dayak Bidayuh community monilitas and the geographically and demographically spread across the borders of Indonesia and parts of Malaysia.

Geographically, the region including Entikong bordering Country Malaysia to the East, located at coordinates 1.130 North latitude to 0.370 South latitude and 111.190 East longitude to 1040 with territorial boundaries as follows:

a) the North is bordered by East Malaysia Serawak.

b) the East borders the Subdistricts Sekayam.

c) the South borders the subdistricts of Sekayam and the Porcupines.

d) the West bordering Bengkayang.

Sub Entikong dintara is one of 15 districts in Sanggau and is located on the front part of the Sanggau which borders Malaysia's Eastern State of Serawak. The Sub has an area of $506.89 \mathrm{~km} 2$ and 5 villages as well as 28 Hamlets.

In demographics, community in district Entikong most profession as farmers, merchants, and service as well as the majority in the village of Entikong. In terms of education and religion, education levels at most at the elementary school level (SD) with the majority of adherents of Catholicism.

If the date based on the mobility of the population, the community in district berinterksi with society often Entikong-Malaysia because trade continues in earnest. In addition, the construction of roads continued to be done so that the mileage of each village semain is easily accessible.

\section{Bilingualisme and Attitude of Language}

The term bilingualisme or being bilingual appears due to symptoms of the use of the two languages or two language codes by community members said in social interaction and gejaia this to be an interesting issue from the perspective of Sociolinguistics. The use of two languages or as a result of the needs of the speaker in communicating. Linguistic ambience like this pose a hassle, because in addition to the need to specify the language should they should be communicating, every speaker needs to also consider the variety of a language where that is appropriate to the situation. Any member of the public said inevitably must choose one language or language variation to be used in the event of certain said. The selection of a language or language variation must consider a variety of factors such as who's talking to whom, and about what and where the events said it lasted.

A speaker should be careful in the selection of language at an event said. Speakers should pay attention to at least two things, namely the need to pay attention to social status (vertical dimension) and social distance (horizontal dimension) counterpart said. Both of these indicators are important, regarding inaccuracies in terms of the selection of the language could pose neither "losses" said for attendees.

To choose the use of one language appropriately in the event of said, one must master both languages, (1) had to master the native language (B1) as his first language, and (2) the acquisition of another language (B2). People can use a second language it is called dwibahasawan or bilingual, whereas the ability to use two languages lands called bilingualitas kedwibahasawanan. In addition to the term bilingualisme with all the jabarannya, there is also the term multilingualisme or keanekabahasaan i.e. the use of more than two languages by someone in his intercourse with others in turn.

With regard to the use of two or more languages in social interactions right memumculkan two characteristics of the society say that is closed and open. The society said 
the society covered untouched oteh said other communities for reasons of geographical location that is remote or was deliberately do not want to connect with other communities said. The society said that as this will still be the Community said that static and remain to be a monolingual society said. While the society is an open society said having links with other communities said allowing the onset of language contacts with all linguistic events as a result and with the help of the Community said that multilingual. Linguistic events as a factor of the contact languages that have an impact on the events of Sociolinguistics in the form bilingualisme, diglosia, code, code, interference or intervention, and the shift of language. All of these are also influenced by the attitude of the bebahasa a speaker who will certainly affect the selection of the right which is considered appropriate language context in communication.

Attitude is the activity of cognition, afeksasi, and tendencies acting someone who is relatively fixed nature. The trend heading into one object, either an individual or an institution. That attitude is a source of cultural, family, and personal. Experts have different opinions about the attitude. Some are assumed, that attitude is a determining factor in the deed, but there is also argued to the contrary i.e. a decisive perbuatanlah attitude. Without the need to sharpen the differences of opinions of experts, let alone argue it compellingly, certainly between attitudes and deeds difficult separated because both have a very tight relationship. Attitude with regard to what was thought, felt, and would like to be done by a person in respect of the existence of something circumstances. While it appears that deeds are always determined by the prevailing social norms, habits are wont to do, and by the thought of what might appear when the deed was done, and not just by sheer desire is based.

If the attitude is associated with language, then one thing cannot be denied that the language is not only an objective, not just tools or instruments that are sosiai to deliver neutral meaning, but relate with the identity of a social group or ethnic. If there are strong links between language and identity of the wearer so that relationship will be revealed in the individual attitude towards the language and the wearer. Individually language serves as a tool and is a maid thought processes at once in sosiai is a tool of social interaction or communication. Language as a tool relies on the human who uses it. In other words evolved and the demise of the language, not the language, as well as the power pemertahanan the language relies on community use.

Language attitude is a mental position or feelings towards their own language or the language of others[8]. In the language of Indonesia said the attitude may be based on body shape, an upright standing position, behavior or gestures, and the deeds or actions taken based on the view of (the founding, beliefs, or opinions) as a reaction to the presence of a the thing or event. Attitude is a psychiatric phenomenon, usually manifesting in the form of action or behavior. Attitude can not be observed directly. To observe the attitude can be seen through a wide range of behavior, but the results showed that what appears in the behavior doesn't always show the attitude. Vice versa, the attitude of a person is not always reflected in his behavior. It also aligns the verbal attitude that difference when communicating between individual ndividu influenced factors of social distance, power, level of imposition against the face of the speaker, the variable social and cultural values[9].

Related to the above explanation, meaning language attitude is very decisive in order to pemertahanan a language because language capable of affecting the attitude of a person to use its language, not the language of others in society, bilingual or multilingual. There are two conflicting language attitude, that is, a positive attitude and negative attitude. The speakers of the language said to be positive when the degree of high scale act or tendencies are strong against the language. His actions were based on a sense of pride, a sense of loyalty, respect, and a sense of conscious of language. Sebaiiknya negative attitude if someone or a group of people no longer have a passion, drive, and a desire to maintain independence of language acquisition. 
Garvin and Mathiot (in Fishman[10]) argues there are three characteristics of language attitude, namely (1) the fidelity of language (language loyalty) that encourage a language community maintain its language and seeks to prevent the existence of the influence of other languages; (2) the pride of language (language pride) that encourages people to develop their language and use it as a symbol of identity and unity of the community; and (3) awareness of the existence of norms of language (awareness of the norm) that encourages people to use language carefully and manners. The attitude of the language became important in order pemertahanan the language because it could influence a person to use language. The attitude of the language associated with the language of loyalty and loyalty when the language associated with a contact in two languages or more could ascertain the community, then theoretically there are three possibilities of usage of language. First possibility would occur or the intermingling of the unification of two languages to a new language eventually gave birth to a commonly referred to as pidgin. The second possibility, the old language "lost's" and shifted by the language that came later to the community so that there was a great shift in the language. The possibility of a third language of the old and new languages co-exist and both languages are concerned the sharing function. In this kind of condition, consciously or not, the old language are retained by the community concerned. This is called with the defending language.

The language of the competition should be diimbangkan with language education. This can occur in the case of the rivalry and the language of the Sundanese in Bandung, Indonesia. Research shows that being bilingual ability and mastery of children (students) against the Sundanese language and language of Indonesia tended to balanced influenced aspects of language structure similarities as there are aspects, compounds, and repeated words[11]. But in terms of publications and advertising the majority language spoken in Bandung Indonesia language dominated (59.6\%), United Kingdom (20.2\%), the United Kingdom and languages mix Indonesia (19\%), and mixed the language of Sunda and Indonesia (1.2\%) (Riadi, $2015 \mathrm{pp}$ 95) This illustrates that it is not impossible that regional languages can hand in seinging with the national language even a foreign language.

Some of the research on the attitude of the language could be made as early as the description of the findings that there are no components that needs to be seen that is the attitude the regional language, national, and foreign languages. Related to this research, then the language attitudes will focus on just two aspects, namely the attitude of Indonesia language as the national language and the attitude of the Dayak Bidayuh language as a regional language. High complexity where the majority of people in West Kalimantan border region included in particular the multilingual is a condition unique to researched. This will be explored on the basis of age and profession with the context of the speech.

\section{Material And Methodology \\ A. Research Methods}

The methods used in this research is qualitative method by using the ethnographic approach to communication. This approach is used to understand the meaning of antaretnik communication symptom. Antaretnik is a communication relationship between individuals of different cultural communication in society diglosik said. Diglosik refers to the understanding of the conditions about the use of language that is stable[9]. The approach will be very relevant in an attempt to describe the attitude of the community language border in the context of international lawyers and trade relation with the world of education.

\section{A. Location, Data, and Data Sources The Study}

Site the study was carried out in the border region in district of West Kalimantan Entikong at Entikong village. The election of the village is based on ease of access and mobility line border trade regions of West Kalimantan-Sarawak. 
The data in this research in the form of speech, now, and the results of interviews collected from in-depth observations on society in the village of Entikong. The data obtained from the interviewees with the merchant profession background.

The data source in this research is the speech of the public at Entikong village. Research in an effort to streamline the adequacy of data then takes the best from a group of researchers (who votes will give enough information) to be selected into the study respondents. Sample to get the data from the instrument on the community drawn from respondents totalling 30 people traders taking into account also the level of his education.

\section{B. Data Collection Techniques}

The techniques used in this research is exploratory sequential engineering. This technique is used to collect data is performed sequentially in the collection. The data is taken either qualitative or quantitative data data will mutually support each other. In this research the collection of data using:

1) Observations

Obsevasi (observation) is a data collection conducted how to observe and take notes systematically investigated symptoms[12]. In this study, researchers observing to West Kalimantan border region (in the village of Entikong) using systematic observation and open. This is done in pengamantan Community policies directly in the selection of a language when communicating in the context of West Kalimantan at the border trade. At certain moments, the researcher does not participate directly but only as observers or observers and not directly involved in the conversation.

2) The interview

In this study researchers using structured interview techniques and deep (deep interview) by some individuals in the community or profession which deals with perdaganagn West Kalimantan border region (village Entikong). This technique will give the advantage to the party which the interviewer in order to guide the talks so as not to get out of the theme. However, this technique takes a good rhetoric and flexibility so that people who were interviewed did not feel awkward. Flexibility is meant here is the possibility to improvise if needed and found unique facts of interest to excavated. It is also done between individuals and groups in a community the same for example when there is a custom event.

3) Question form or the Questioner

Question form or the questioner is a list that contains a series of questions about something problem or fields will be explored[12]. This is in line with the opinion of the Arikunto[13] that the now or the questioner is a number of written questions which were used to obtain information from the respondent. Question form or the questioner in research aiming to get an idea of the attitude of the West Kalimantan border community language in the realm of international trade.

\section{Result And Discussion \\ 5.1 Results}

Indonesia is a vast archipelago country's territory stretches from Sabang tip of Sumatra to Marauke in Papua. Not only in terms of geographically but in terms of demographics, in Indonesia there are also many different tribes and cultures and languages. That diversity needs to be politically unified through a system of the Constitution and the language of unity which in this case is the language of Indonesia.

The official Indonesian Language became the State language increasingly undertaken in various domains of life and the realm of reason. From the realm of life, Indonesia language tips are established status and its use in formal variety. While the regional variety of language Indonesia, kian as alternative language in communication antaretnis in various areas and the 
border region was no exception as in West Kalimantan. Related to that, following various studies of tekait on the border of West Kalimantan Indonesia language.

The results of observation and research now shows that the society of merchants and consumers in particular Entikong (from among adults and students) who trades in the territory of Indonesia Indonesia language tend to use if different tribes. In addition, the community of merchants and Entikong in particular consumers who transact in Malaysia region will tend to use the language of Malaysia who mixed with the local languages (Dayak Bidayuh or Malay). This suggests that the language is determined by the attitude of the situation and the context of the speech is going on. In addition, the context of the second relationship is affected also by intercultural communication skills acquired at school and multilingual language proficiency so that communication in the context of trade.

The data is taken from the original merchant Indonesia 20 people (10 men and merchants in West Kalimantan region 10 relic traders of Sarawak) and 10 consumers (5 people in West Kalimantan region consumer and consumer 5 relic in Sarawak) that total respondents as many as 30 people. The data in the form of speech which describes the language attitudes in this respect is the selection of languages by the Community border is affected by the context. If it is Indonesia's trade relic then society will tend to use the language of Indonesia if different tribes. But local languages are also used when merchants and consumers to Transact. Unlike the trade in the region of Serikin (Sarawak, Malaysia) most pedagangnnya are people of Indonesia. In the village, the market opened only on weekends and product origin Indonesia is the best-selling products are sold. These products are mostly in the form of accessories and pakayan. Many leaders Malaysia are shopping and this affects the language chosen by the merchant sala Indonesia. They will use the language of Malaysia and a currency, the ringgit.

The selection of languages and intercultural strategies influenced also by level of education. 20 the respondents have attended at junior level and senior high school and the rest only attended primary school. Indonesia's language learning experience in schools and direct communication with strangers border region has given education speak so stretegi speaking the language and the selection is not an issue for them.

\subsection{Discussion}

\subsubsection{The Position and The Function of The Indonesian Language}

The position and function of the language relating to the legality and policy of political and sociological about the use of language. In this context, the position and the function of language in question refers to the national language bahasa Indonesia.

The history of the development of the language of Indonesia started from the development of the Malay language as the lingua franca and the forerunner of the Indonesia language. Indonesian Language has long been part of the history of the independence of the nation of Indonesia. Since the language is set to become the official language of the State and unity on 28 October 1928, Indonesia had a major role against the nation of Indonesia, both in the colonial rule, independence, as well as the present. Indonesian Language capable of uniting the Nations of Indonesia and make the nation of Indonesia aligned with other Nations. The role of language Indonesia is huge in the colonial era. Indonesialah language that is able to unite the entire region in Indonesia so that national consciousness arose that made the nation of Indonesia is able to repel the invaders and became independent. The spirit of nationalism is high at the moment it makes language development Indonesia very rapidly because everybody wanted to show his true identity as a nation of Indonesia.

The placing bahasa Indonesia as the State language in the Constitution of Indonesia 1945 article 36 has been placing bahasa Indonesia language as the language of science and the mass media, including the language of instruction in the implementation of the nation's 
education in schools and universities all over Indonesia. Indonesian Language is also used as an official language by local governments throughout Indonesia. It is also reinforced by Law No.24 year 2009 article 25-45 that insists on the use of business, internationalization, and institutional language created for the benefit of development and construction of the language of Indonesia.

In addition, the position of Indonesia language was strengthened through the world of education. It is exercised by the Ministry of education and culture of Indonesia who formulated and obliges Indonesia language education and their use in the institutions of the school at a basic level to higher education. It is also supported by the language centre as a development education institutionin Indonesia. Various innovations done from level curriculum to educators quality improvement efforts. So also on the institution of language in this language centre was founded by RI also is constantly working to provide the construction through a variety of training for language teachers, the construction of the language through socialization, until menyemarakan day Sumpah Pemuda by involving students. It is also inseparable from its function as institutions that set the rules of a good language and appropriate context through social development approach.

Relation to this study, the researchers will analyze the position and function of the language of Indonesia in West Kalimantan border areas. It is important to get the data about how the use of the national language of relic exist with various ethnic groups. If found a number of constraints or shifting of the position and the role it will be harsher solutions how to both languages remain in their respective koridornya as a means of communication.

\subsubsection{The Attitude of Indonesian Language Community on the Trade Context}

Through the answer sheets of the instrument of observation and interviews, didapatlah data about the attitude of villagers speaking Entikong that profession as a trader. There are four main instruments so main languages are:

1. The use of the Indonesian language in the linguistic situation of the (formal and informal) to figure out the position of the language.

2. Indonesia language Usage in a variety of domains to figure out the function of language.

3. Loyalty society against the Indonesian Language to gauge the attitude of the language in the realm of trade.

4. Level of education towards the knowledge and skill to communicate.

5. Strategy defense language of Indonesia in West Kalimantan border area

At first, the majority of respondents to the instrument as much as 23 people wear formal situation in Indonesia language (office, school, and the center for public service) and 7 people using local languages. In colloquial situations like trade and offer services, languages selected language is the language of the majority of the region and Malaysia as much as 28 people and 2 people keep using the language of Indonesia because it is considered neutral and can be used in various situations including trade. They are minded to facilitate communication if the settlers are dealt face or a different tribe.

On the second insrumen, the majority of respondents as many as 25 people know the function of the language of Indonesia as nesional language that is used when the situation is formal and 5 people not knowing for sure the concept of the use of the national language. While trade and shop they will adjust the opponents said they use what language as needed so that the transaction runs lancer and mutual benefit.

On the third instrument, a majority of respondents as many as 15 people loyal to use the relic in bahasaIndonesia trading Indonesia and 15 people tend to choose the language of the local area to trade in the territory of Indonesia considered most the community is multilingual. Applies if the relic is Malaysia trade then a majority of respondents would use Malaysia as much as 26 people and 4 people using local languages which happens to be equal to their 
tribes. This shows that trade interests include adjustment of cultural and linguistic expression in a region strongly considered.

On the fourth instrument, a majority of respondents a total of 11 people educated end high school that language learning in schools in the past provide enough knowledge and attitude of the nationalist, an educated person and 9 end of junior high school also stated it the same. In contrast to respondents who graduated elementary school or have not completed elementary school as many as 10 people who admitted to not feeling getting a meaningful learning experience and attitude of nationalism against the use of the language of Indonesia for their trading business. They assume a very traditional thing of their education is not their illiteracy and can write, counting, and reading. They communicate naturally fit speakers make their opponents to talk. In contrast to those who graduate high school who admitted passing experience learn they are more matter against national languages and learning outside the school also form the attitude of loyalty speaks with interaction with society settlers the outside areas or out of State.

On the fifth instrument, the majority of respondents as many as 17 people agree to hold the linguistic socialization or things related to language in the curriculum about as if in an attempt to pemertahanan the national language. But as many as 13 people reject the existence of such activities because it is considered would only spend time because their profession as a trader which is full of high mobility dikedua trade area countries. However, it does not cover the possibility of socialization is held with the right way without interrupting trading activity can be conducted by related agencies. It is important to provide language education outside of school or institution to direct attitude to political benarsesuai ang national language and also teaches how intercultural communication takes place.

\section{Conclution}

The border area is an area that will really be of particular concern to the Government, for the development of border areas become an incredible asset for a country. The constraints experienced by the villagers Entikong especially in the lack of knowledge about the rules of the language are expected to be addressed by means of socialization about the regulations related to the use of the languages of Indonesia and foreigners in the area.

\section{REFERENCES}

[1] B. P. dan P. Bahasa, UU RI No. 24 Thn 2009 tentang Bendera, Bahasa, dan Lambang Negara serta Lagu Kebangsaan. Jakarta: Kemendikbud RI, 2011.

[2] S. Darmojuono, "Peran Unsur Etnoprogramatis dalam Komunikasi Masyarakat Multikultural," J. MLI, vol. 29 Februar, 2011.

[3] N. C. J. L.A. Samover, R.E. Porter, Understanding Intercultural Cummunication. Wadsworth.

[4] D. Soepardjo, Komunikasi dan Hubungan Personal Orang Jepang. Bintang, 2008.

[5] J. C. McCrorkey, Oral Communication Apprehension: A Reconceptualization. Communication Yearbook 6. Beverly Hills: Sage, 1982.

[6] R. E. C. D.W. Klop, "Communicatoin apprehension among college students in America, Australia, Japan and Korea," J. Psichol., 1979.

[7] S. Sanggau, Profil Kecamatan Entikong. Sanggau: Pemda Kabipaten Sanggau, 2015.

[8] H. Kridalaksana, Kamus Linguistik. Jakarta: Gramedia Pustaka Utama, 2001.

[9] Suyito, Pengantar Awal Sosiolinguistik Teori dan Problema. Surakarta: Henari, 2006.

[10] J. A. Fishman, The Sociology of Language. Rowley: Newbury House, 1972. 
[11] D. Huri, "Penguasaan Kosakata Kedwibahasaan Antara Bahasa Sunda Dan Bahasa Indonesia Pada Anak-Anak (Sebuah Analisis Deskriptif-Komparatif)," Pendidik. Uniska, vol. 2, 2014.

[12] A. A. Cholid Narbuko, Metodologi Penelitian. Jakarta: Bumi Aksara, 2013.

[13] S. Arikunto, Prosedur Penelitian Suatu pendekatan Praktek. Jakarta: Rineka Cipta, 2010. 